\title{
Identity formation of the profession in a latecomer political science community
}

\author{
Gábor Tamás Molnár ${ }^{1} \cdot$ Gabriella Ilonszki
}

Accepted: 9 November 2020 / Published online: 2 February 2021

(c) The Author(s) 2021

\begin{abstract}
Latecomer political science communities have faced multiple challenges in the past decades, including the very establishment of their professional identities. Based on the case study of Hungary, this article argues that publication performance is a substantial component of the identity of the political science profession. Hungary is a notable example among Central and East European (CEE) political science academia in the sense that both the initial take-off of the profession and then its increasing challenges are typical to the CEE region. In an inclusive approach, which encompasses all authors published in the field between 1990 and 2018, as well as their publication record, the analysis demonstrates that political science has undergone major expansion, quality growth and internationalisation but these performance qualities are unevenly spread. These reflect important aspects of the profession's identity. This agency and performance-based approach to identity formation might well be used to build up identity features elsewhere and also in a comparative manner.
\end{abstract}

Keywords Political science $\cdot$ Professional identity $\cdot$ Publication performance . Internationalisation $\cdot$ Skewness

\footnotetext{
The article has grown out of our involvement in the COST Action CA15207: Professionalization and Social Impact of European Political Science (PROSEPS) project. Thank you to the colleagues in Working Groups 1 and 4 for their inspiration and encouragement.

Gábor Tamás Molnár

gabortamas.molnar@uni-corvinus.hu

Gabriella Ilonszki

gabriella.ilonszki@uni-corvinus.hu

1 Department of Public Policy and Management, Corvinus University of Budapest, Fôvám tér 8., Budapest 1093, Hungary

2 Department of Political Science, Corvinus University of Budapest, Fővám tér 8., Budapest 1093, Hungary
} 


\section{Introduction: studying the identity formation of new professions}

The political science profession is changing fast: internally, new fields, subfields and new methods emerge, while externally new expectations structure it, restructuring our understanding of the role and thus the identity of the profession (Boncourt et al. 2020; Klingemann 2008; Krauz-Mozer et al. 2015; Mény 2010). In reflecting on these points, it remains an important question as to how political science becomes or remains distinct from other professions, how it is recognised and how it creates its visibility. These are all key aspects of its identity. Moreover, it is also apparent that a profession cannot stabilise and adapt if its identity foundations are not clearly settled. In this sense, a clear identity of the profession provides a status in academia and helps to establish an acknowledged institutional position. This is because such a status will serve the profession and will provide a standing for those who cultivate it. While the identity of professions is based on the recognition of the group (Mény 2010), this group recognition is embedded in its composite membership. This is the focus and the question of this research article, namely how do the actors involved add to the identity formation of the discipline? Yet, this answer is particularly hard in case of new political science communities given the absence of firm legacies and the lack of actors that have sound background in the field.

In looking at these issues in more detail, a review of the scientific literature on latecomer political science communities highlights that this is mainly in the form of qualitative case studies, which focus on theoretical, methodological and institutional developments either at a regional (Eisfeld and Pal 2010; Ghica 2020; Klingemann 2008; Krauz-Mozer et al. 2015) or at a country level (Chiva 2007; Gel'man 2015; Kasapović 2008; Szabó 2002). These are important starting points for understanding the professionalisation processes, but they do not offer results on an important aspect that - as this article argues_-structures the identity of a professional community, namely its performance. On the other hand, a few bibliometric studies focus on latecomer political science communities (Jokić et al. 2019; Schneider et al. 2013) that highlight some performance trends. However, due to their focus on smaller crosssections of political science publication activities, they do not study the identitybuilding of the discipline in that frame. This study proposes a multifaceted approach to study professional identities based on the main professional activity of the community that is scientific publication, supplemented by data on the personal identities of the authors. We apply this inclusive, data-driven approach to the latecomer Hungarian professional community over a three-decade long period (1990-2018). The single-country case study design is justified by the unusual depth and breadth of the data collection process, providing a comprehensive overview that can serve as a starting point for future comparative studies. After introducing the proposed theoretical frame and the research questions, the article will place the selected case in a Central and East European comparative frame and will formulate expectations on that basis. After explaining the methodology, the main body of the article examines the development of Hungarian political science's professional identity. The conclusion discusses the results in the light of recent developments and identifies prospective research directions. 


\section{Approaches to professional identity}

There are two main trends in the literature to explain the foundations of professions' group identity. The first emphasises the organisational aspect. The second focuses on the identity of those who apparently constitute the profession. In the former, the focus is on the institutional level, namely organisational aspects that establish the foundations of the group: who they are, where they belong to, and what structural-organisational attributes they have. In this context, such factors as standardised training, a certificate of competence (e.g. a Ph.D. in political science), institutional membership and employment in the practice of the profession tend to appear as the foundations of the group (Rose 1990, p. 581).

In the second aspect, group identity appears as an agency issue. In other words, how do those who are part of the group identify themselves? In this regard, a "professional identity (...is) a unique construction of who one is" (Caza and Creary 2016, 79). This literature also posits that people in the professions have multiple identities. It seems that there is no "cognitive exclusiveness" that used to make the professions of old times develop and be safe within their own realm with an identity only of their own (Larson 1977). These two aspects only partially apply to newly developing professional communities, where both the structural foundations and personal professional belonging can be widely shifting and make identity formation uncertain. Although the organisational attributes become invigorated with time in newly established professions, the formation of group identity cannot be safely built on these types of institutional-organisational components. For example, in Hungary in 1989 nobody had political science training, not the least a Ph.D. in the field, and although a political science association was in existence since the early 1980s, its profile was not clear, and even employment in the field of political science was for a long time uncertain (Szabó 2002). Hungary was not alone in this regard as this state of affairs was basically the same in all post-communist countries. ${ }^{1}$ Building the concept of a professional community on the self-identification of agents is similarly problematic in these countries: several professionals widely recognised as key contributors to Hungarian political science did not identify themselves as political scientists, while many self-identified political scientists did not contribute scientifically to the field. This article proposes an additional aspect to unfold the identity of the political science profession-namely performance. We argue that the identity of the community is mainly an internal construct: it is formed through the actions of those who contribute to the key practices of the group, fundamentally to academic performance. Figure 1 shows how we position this analytical framework in the literature about identity.

The proposed approach allows for multiple identities similarly to the agencybased approach, as professionals can be active contributors to multiple professional communities irrespectively of their organisational belonging. The article will posit that whoever contributes to the political science profession will

\footnotetext{
${ }^{1}$ For a recent overview on the identity background of the "founding fathers" of political science based on a survey of political scientists, see Ilonszki and Roux (2019).
} 


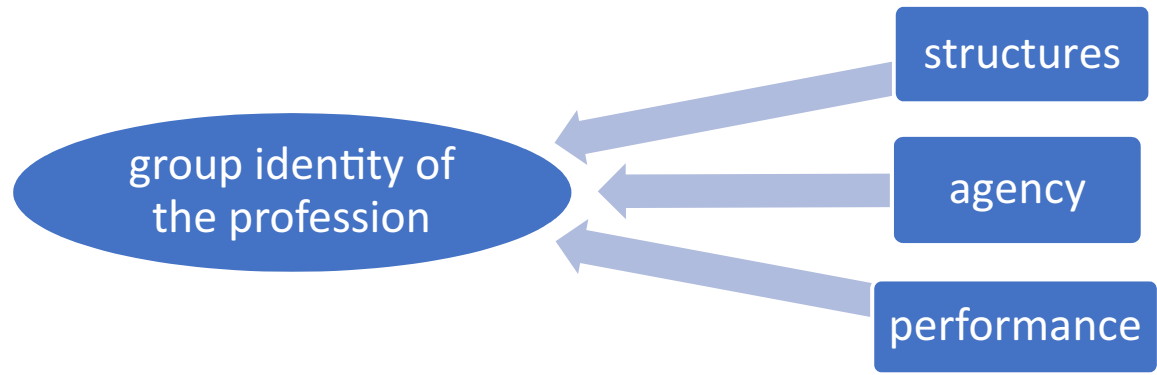

Fig. 1 Framework for a profession's identity formation

add to its identity - will add to its status and make it recognisable for others on this basis. This leads to a more inclusive concept of the professional community: the individuals involved connect through their activities in the field. While designed in response to some challenging aspects of latecomer communities, this approach might be fruitful in studying other political science communities as well. As disciplinary and institutional affiliations as well as personal academic identities become generally more complex and fluid, a flexible and inclusive framework could yield a more accurate picture of the profession.

\section{Research questions}

The above framework allows us to construct the identity formation of the discipline by presenting and connecting the personal composition and the performance composition of the Hungarian political science community. This leads to two broad research questions.

RQ1 How did the political science community expand during the last three decades?

RQ2 How did the publication performance of the professional community evolve over the last three decades?

While our approach presupposes a largely internal drive in the profession's identity formation (the actors involved identify with the field and tend to perform accordingly), different policy actors have a role in this process. Nevertheless, despite the increasing push to publish (or perish) academic research and publication are fundamental for the healthy state of the discipline (Drennan et al. 2013) as they promote the profession's adaptive potentials and thus irrespectively of the external push they add to the profession's identity. 


\section{Expectations: political science in CEE and Hungary}

The large majority of post-communist countries could not build on substantial pre-communist local legacy relating to political science and although their communist era was far from identical most of them could not establish political science during the communist decades either. The only exceptions in this regard were Poland and Yugoslavia, but their relative advantage remains controversial, as scholars have pointed out that the two countries could not significantly capitalise on it (Boban and Stanojević 2021; Gebethner and Markowski 2002; Mény 2010). Thus, the analysis offered in this article focuses on the professional identity formation in the "new" era covering the post-communist period only. Hungary is no exception to this, with political science only becoming established with the fall of communism.

Hungary follows the trajectory of most countries in other aspects as well. Although initially Hungarian political science seemed to be a forerunner, more recent developments show that it is facing problems very similar to most countries in the region from precarious funding through decreasing student numbers to disputed relevance (Világi et al. 2021). Hungarian higher education, together with that of the Czech Republic, Slovakia, Latvia, Lithuania and Poland also suffers from diminishing student and staff numbers (Pruvot et al. 2018, p. 19). Political science is not immune from the effects of that general trend. For example, in 2018 Hungary was among the larger political science communities of the region, being second only to Poland and comparable to Lithuania, Romania and Slovakia. However, at the same time in 2017 it had the lowest number of Ph.D. candidates in political science among the larger countries, with this being a sign that political science as a professional career seemed to have lost its attractiveness.

The identity frame of this article encompassing the performance aspect of identity formation is all the more interesting as the scientific output originating from the region is also still below its potential in both quantity and quality (Ghica 2020, p. 169). In this regard, Hungary seems to have some comparative advantage as it enjoys a central position as the most regionally connected national community in terms of co-authorship in CEE (Jokić et al. 2019). Not unrelated to that it was an early "internationaliser" as exemplified among others in terms of ECPR membership (Berndtson 2021) that might well increase the sources for publication, such as connectedness, networks or funding. As for the overall regional publication pattern, although the research findings are limited, they nevertheless establish some baseline points regarding the Hungarian case. In the first place, the publication output of political science in CEE has been growing along with its bibliometric quality (Jokić et al. 2019). On the basis of preliminary research, this article seeks to confirm this trend in the Hungarian case. In addition, in face of the development of the profession particularly in training and quality assurance mechanisms, we also anticipate increasing quality of the publications. We can rightly expect more publications from authors who are increasingly qualified to pursue the profession, who work in a (relatively) safe and stable environment, and who face normative expectations. The numerical aspect is thus complemented 
with fundamental changes in some quality aspects of publications. Furthermore, an increased international component may also add to the publication features. At the same time, however, there are well-founded doubts whether these positive patterns prevail all over the entire profession in Hungary. The professional communities in Central and Eastern Europe are often fragmented, which might manifest itself in uneven research performance among members as the cohesion of the discipline is largely lacking (Eisfeld and Pal 2010, p. 234).

\section{Methods}

\section{Operationalisation}

In an iterative approach opting for maximum inclusion, data collection began by creating a list of political scientists based on their institutional affiliations, self-identification and contribution to the flagship Hungarian political science journal, Politikatudományi Szemle (Hungarian Political Science Review). After compiling their complete list of scientific publications, we repeated the classification process for all of the co-authors until we found no new contribution or person linked to Hungarian political science. This added up to the complete scientific publication data for all professionals who contributed to Hungarian PS and/or had institutional connections with it. The resulting primary database has individual authorships (author-publication combinations) as observations.

\section{Data}

The main data source was the Hungarian Scientific Bibliography (MTMT) official database (Holl et al. 2014). This is an unusually complete and detailed data set as scholars are expected to maintain up to date their MTMT profiles as part of the performance evaluation systems. Records in the database are validated by official institutional and central administrators. MTMT has already been used to study patterns of publication performance in Hungarian academia (Sasvári and Nemeslaki 2019), but this article goes beyond this earlier article both in depth and spread. First, for the authors without complete MTMT profiles we compiled bibliographies through numerous other sources. ${ }^{2}$ As a result, this database is more encompassing as it includes all authorships for all journal articles of political scientists and contributors-irrespective of language, length, or format from commentaries through research notes to "proper" research articles. We also complemented biographic data from the same sources for incomplete or missing MTMT profiles. In addition, we

\footnotetext{
${ }^{2}$ These include their personal or institutional pages, Google Scholar, ResearchGate, Academia.edu, LinkedIn and by querying academic meta-search engines (EPA-HUMANUS-MATARKA, National Széchényi Library catalogue). The supplementary publication data were found to be comparatively reliable only for journal articles, so we focus on journal articles for most analyses, with checking robustness on a restricted (MTMT) sample including books and book chapters.
} 
also constructed a secondary panel database on publication performance including books and book chapters, with author-year combinations as observations, to allow for analysis based on the whole active population for a given period. For the general population, the most reliable and comprehensive comparative performance measure in the database is scientific journal articles, therefore most of the analysis relies on those.

\section{The analysis}

\section{The professional community}

On the above grounds all potential performers with their performance appear in the database and it is possible to create four groups with particular connections to the Hungarian political science community. The political scientist group contains those whose involvement in political science is clear through their institutional affiliation or their self-identification in their professional profiles and through their publication activity as political scientists. The second, i.e. the contributor group's members are not affiliated to a political science institution and do not identify themselves as political scientists but have contributed with at least two publications to the field of political science. They comprise two typical subgroups: those who are not in academia, but publish in political science (advisors, politicians, diplomats), and those academics who are clearly not political scientists yet still publish in political science. The third group is the so-called outsider group, whose members have less than two publications in political science. In our database, they mainly appear as co-authors with political scientists or contributors, but this group also includes those who publish only once in political science. This latter subgroup consists of students of political science who publish once before leaving the profession and academia or real outsiders who, once in a lifetime, publish in a political science-related topic, but represent another profession. It is an important aspect of the profession's identity development how the share of contributors and outsiders changes as compared to political scientists per se: their shrinking share as compared to the group of "true" political scientists might indicate a more compact political science community, while their stable presence will hint at a multifaceted profession.

The final group, foreign contributors, appear in the database as co-authors but have no Hungarian institutional affiliation. To qualify for any of the non-foreign groups, we required an author to have Hungarian affiliation for a given year, and only considered positions at international institutions based in Hungary (such as Andrássy Universität Budapest and CEU) as Hungarian affiliations if the professional was involved in publishing, teaching, supervisory or associational activities within the Hungarian political science community.

Table 1 provides an overview of some important features of the four above mentioned groups. We cannot neglect the outsiders or the foreigners: their mere 
Table 1 Demographic composition of the profession

\begin{tabular}{lllll}
\hline Author group & Political scientist & Contributor & Outsider & Foreigner \\
\hline Frequency & 325 & 202 & 1070 & 555 \\
Share of MTMT profiles & $88.3 \%$ & $83.2 \%$ & $67.9 \%$ & $0.2 \%$ \\
Share of female & $23.7 \%$ & $23.3 \%$ & $37.8 \%$ & $35.7 \%$ \\
$\begin{array}{l}\text { Average length of academic career } \\
\quad 17.8\end{array}$ & & 21.3 & n.a & n.a \\
$\quad$\begin{tabular}{l} 
Average age at first publication \\
\hline
\end{tabular} & 28.1 & 26 & n.a & n.a \\
\hline
\end{tabular}

numerical presence and their rightly expected performance certainly form the features of the profession. The groups of the political scientists and the contributors are less numerous $\left(325\right.$ and 202 , respectively ${ }^{3}$ ), while they certainly show more internal stability and higher performance levels than outsiders or foreigners (see Fig. 2). Women comprise less than one-fourth in the political scientist and contributor group, while more than one-third among the outsiders and foreigners. The average length of careers (given the twenty-eight year-long observation period) gives the impression of an established and person-wise internally stable discipline. The average age at first publication is surprisingly low which strengthens the former observation on career length. Close to ninety per cent of political scientists have the MTMT publication portfolio. Since MTMT was launched in 2009 and has become the official basis of performance management in Hungarian academia, those colleagues who did not maintain MTMT profiles were either affiliated exclusively to international institutions or retired or deceased by the time MTMT got into use.

Figure 2 might look complex at first sight as it shows the features of the community through both measurement foci. The four grouped bar charts represent the size of the four groups of performers and their numerical change over time, while the two line diagrams show the rate of publication activity of the most decisive groups that is political scientists and contributors.

In Fig. 2, the sample of journal articles comprises all scientific articles irrespective of language and quality impact. As for the number of persons that appear as political scientists or contributors the picture is straightforward: the number of active political scientists increased more than fourfold (more precisely from 71 in 1990 to 321 in 2018); the increase in contributors was less dynamic but still more than twofold (from 85 to 196), and except for the first post-transition years that is from 1994 onwards the number of political scientists was persistently higher than those of contributors. Political scientists per se have unquestionably become the dominant group among the performers.

Although the growth rate has slowed down for both the political scientist and contributor groups in the last decade, the stagnation was more noticeable in the number of contributors. We can rightly claim that numerically the size of the political

\footnotetext{
${ }^{3}$ It is important to note that a mere structural-organisational approach would imply a smaller number of political scientists.
}

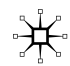




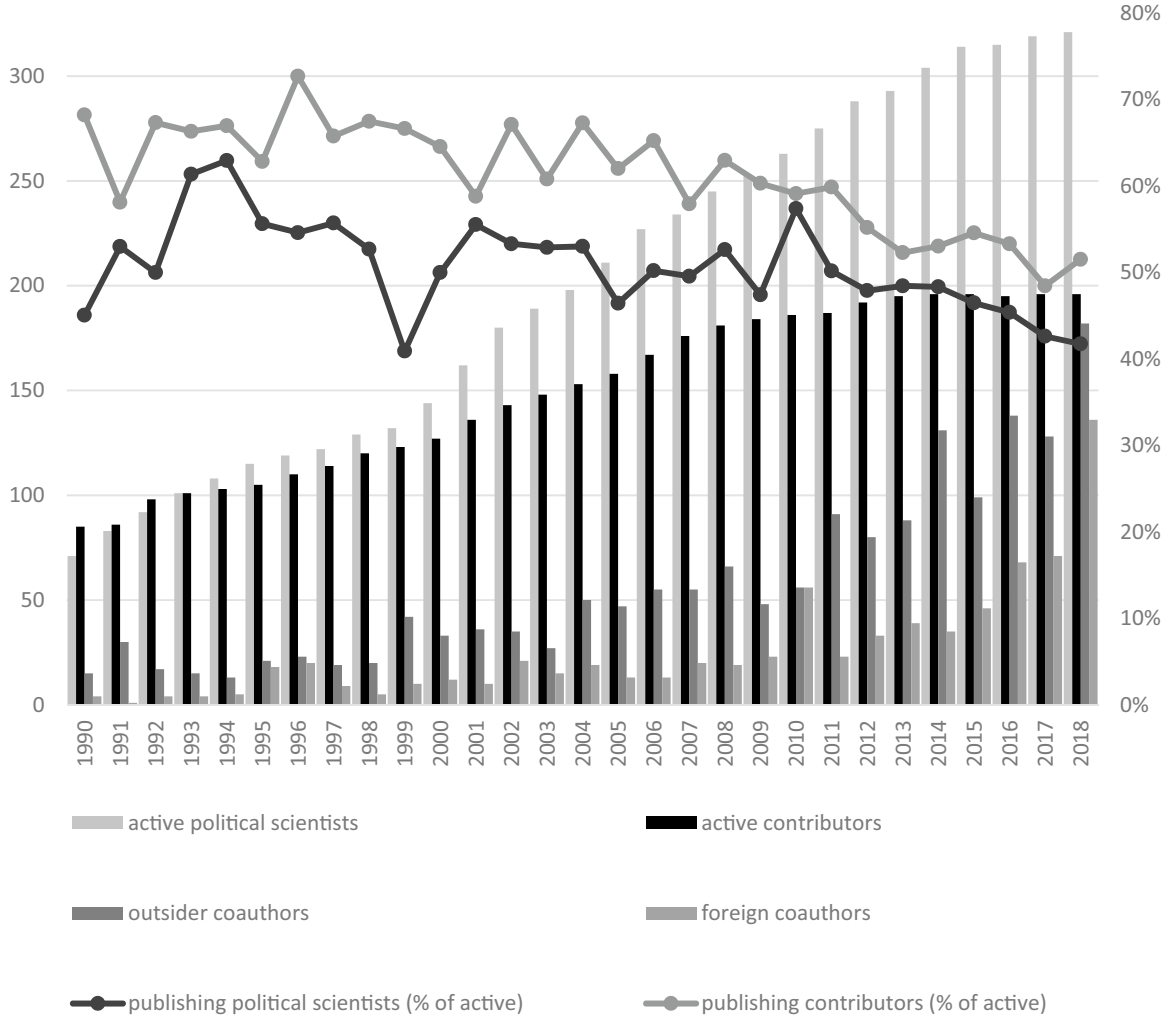

Fig. 2 Size and publication activity of author groups with regard to journal articles

science community possibly has reached its peak. New institutions-either within universities or outside as research organisations-have not been formed in recent years. At the same time, we can observe a clear increase both in the outsider, and particularly in the foreign co-author group. This hints at more intense cooperation between foreign co-authors and the political scientist and contributor groups. Somewhat in contrast to this increase and stabilisation of the political scientist and contributor groups at a potential peak, the line diagrams show decline in their per capita publication performance. The number of political scientists who publish each year stagnates (around fifty per cent) while in case of contributors there is a clear decline in the past decade.

\section{Publication activity}

While the preceding analysis was based on all journal articles, Fig. 3 allows a more in-depth look as it features various types of publication performance per capita. The most striking result is that the increase in scientific publication activity of Hungarian political scientists mostly occurred because more authors entered the field and not 


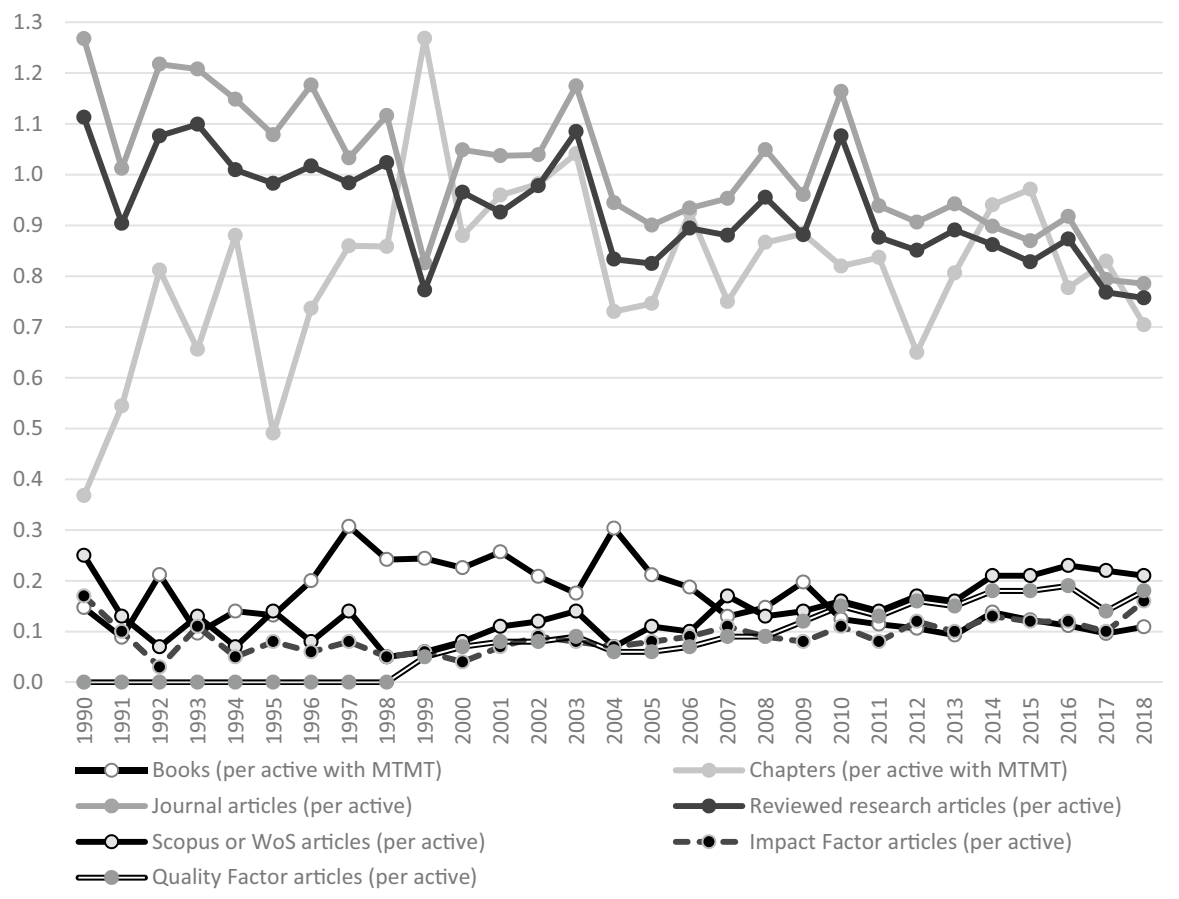

Fig. 3 The extent and structure of the publication activity of political scientists

because of increasing per capita performance. This led to a steady increase in overall output, but no major improvements comparable to the rise in publication output of European political science from 2006 to 2013 (Schneider 2014).

The data also highlight that there is an element of fluctuation in the yearly output per capita, which initially increased then slightly decreased for books, chapters and journal articles. Although this is less surprising for books and chapters as they tend to have lower weight in performance assessment, it is somewhat troubling in the case of journal articles given their significance for professional standing. We can observe the only substantial "improvement" per capita in the rise of articles published in journals with Quality or Impact Factor, while the per capita number of articles indexed in Scopus or WoS only slowly increased to reach its 1990 level. There could be survivorship bias behind the early drop in average performance, as for those years we are more likely to have data on indexed articles and their authors, but the stagnation (in research articles) and slow growth (in high-quality articles) still persists if we compare those numbers to the late 1990s. One explanation could be the transformation of personnel structure: during the early years of the profession, the few authors who published research articles had the international connections and capacity to appear in internationally indexed journals. With the expansion of the field and the many new entrants, less prestigious, domestic research journals became more frequent publication forums. The growth in Scopus-indexed articles and the upward turn in performance after 2010 aligns with earlier results for the whole region (Jokić et al. 2019). 
This initial focus on the rapid expansion of publication output lasted until the end of the 1990s, when the gap between books, chapters and general research articles on the one hand and internationally indexed articles on the other was the largest. After 1999, the shift from quantity towards scientometric quality became ever clearer, as the increasing share of journal articles in total output and the shift within journal articles demonstrate. The gap between the number of all journal articles (including those not reviewed or not present in Scopus and WoS) and higher-quality articles clearly declined, as the discipline adapted to changing performance expectations over time and almost completely abandoned scientometrically disregarded categories. $^{4}$ An alternative explanation could be that we slightly overestimate the expansion of the profession by not excluding non-publishing colleagues from the active category, thus underestimating the per capita output of active colleagues.

The role of local (CEE) journals becoming internationally recognised in increasing publication quality noted by Jokić et al. (2019) is corroborated by our data. While articles in foreign journals went from being indexed in Scopus thirty per cent of the time throughout the 1990s to being indexed sixty to seventy per cent of the time in 2018, for Hungarian journals this ratio increased from almost no Scopusindexed journal articles in 1990-2004 to around ten per cent in 2016-2018. By 2010 as many as thirty to forty per cent of Scopus-indexed articles by members of and contributors to Hungarian political science appeared in Hungarian journals, and twenty to thirty per cent of them still do for our latest available years.

The growth in QF and IF articles from the middle of the 2000s coincides with an increasing focus on high-quality research output at leading institutions, as well as more steadily available funding for such endeavours. Although local and national resources remain limited, some increase in international cooperation also supports this type of quality performance. As for the range of internal resources two or three research projects tend to win financial support from the national science foundation (OTKA and later NKFH) in the field of political science on a yearly basis. Some additional competitive funding is available for young colleagues, limited to three or four grants per year. Exceptionally, leading institutions provide funding for open access appearance to encourage quality as well as visibility of publications. Altogether however quality publications are frequently connected to involvement in international projects (see Table 2).

The trend in international publications also appears as one explanatory source of the contrast between growth in quality and stagnation in per capita research output. Figure 4 compares authorship patterns for internationally indexed reviewed articles. The lines show the dynamic of the average number of authors, while the stacked areas show the growing share of co-authorship for research articles indexed by Scopus or WoS.

Looking at the average number of authors, the growth in co-authorship intensified from 2010, and is much higher for internationally indexed articles. The distribution paints a similar picture: the share of single-authored articles declined in

\footnotetext{
4 Note that Hungarian political scientists still engage in plenty of non-peer-reviewed publication activities, but non-scientific publications were excluded from the analysis.
} 


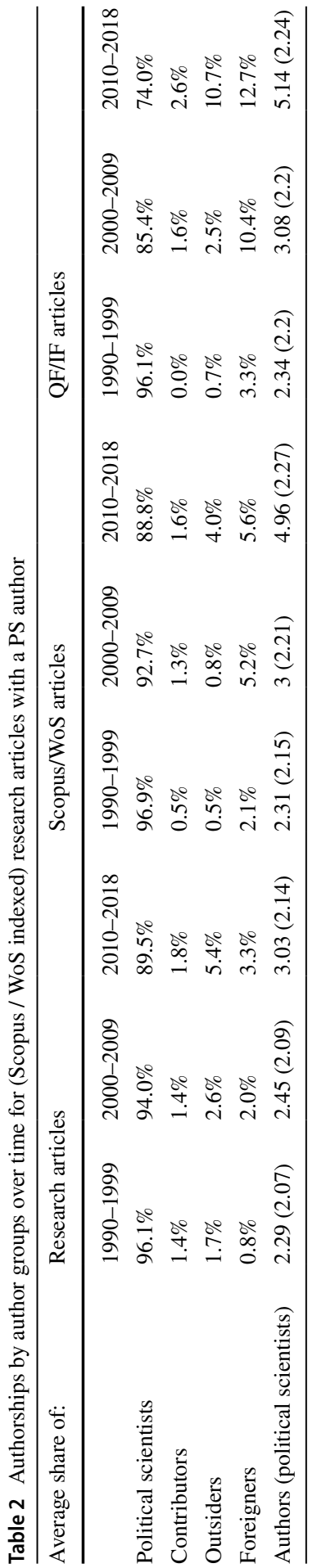




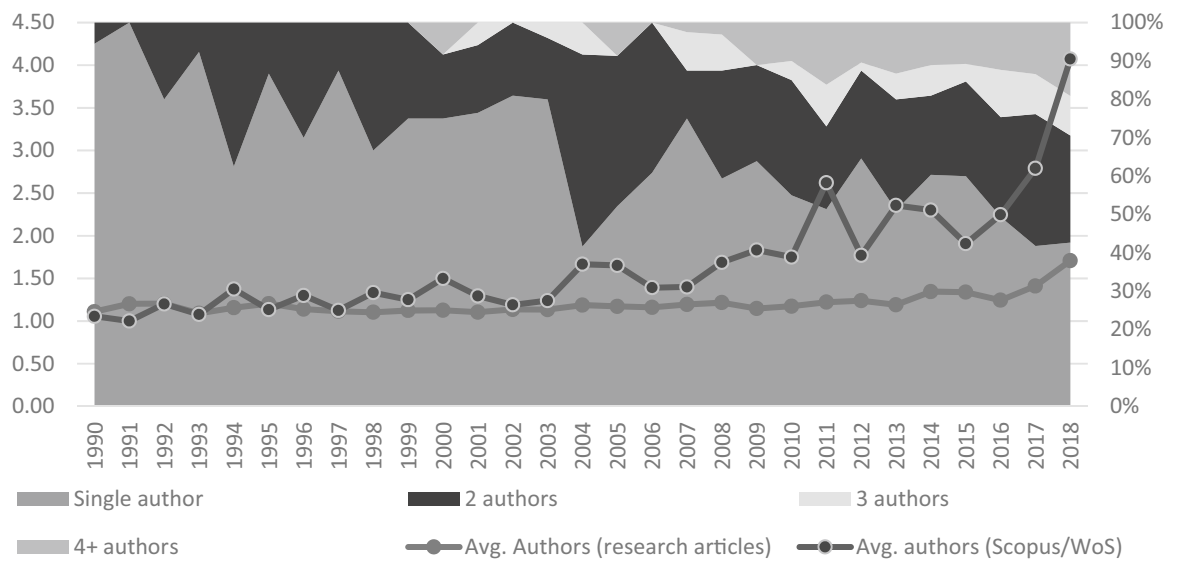

Fig. 4 Co-authorship patterns for internationally indexed research articles with a political scientist author

all samples, while articles with several authors became more prominent, and both these trends were stronger for internationally indexed articles. Hungarian political science had a noticeably higher share of co-authorship than what was observed for the subsample of comparative politics in CEE (Schneider et al. 2013) and for political science in the region (Jokić et al. 2019). The levels observed in our data would put Hungarian political science among those with the highest rates of co-authorship in the region, and very close to results on global political science (Metz and Jäckle 2017). Compared to data on the WoS-indexed part of political science, this puts the level of co-authorship in internationally indexed Hungarian political science scholarship as slightly below average until the mid-2000s, and clearly above average after that (Henriksen 2016).

Co-authorship thus seems to be one of the driving forces behind the increase in high-quality publications, but with what groups did political scientists cooperate? Table 2 demonstrates that some of the growth in co-authorship occurred through denser cooperation within the profession, as the average number of political scientist authors per article increased slightly.

Despite their significant share of PS article authorships, the share of contributors as co-authors to political scientists is quite low, with negligible growth. This suggests that while contributors engage in political science scholarship, they do not cooperate intensively with core political scientists. The increase in the share of outsiders as authors along with their rapidly growing number shown in Fig. 2 hint at the opening of Hungarian political science towards other professions within Hungary (they are the outsiders) and foreign colleagues especially in the last decade. Just to provide the most extreme (or the best) example: in the last year in our database in the group of IF/QF articles authors from outside of core political science represented one-fourth of all authorships, and outsiders and foreign co-authors were dominant within that group. As we proceed in time, the share of contributors and foreign contributors has been rising. 


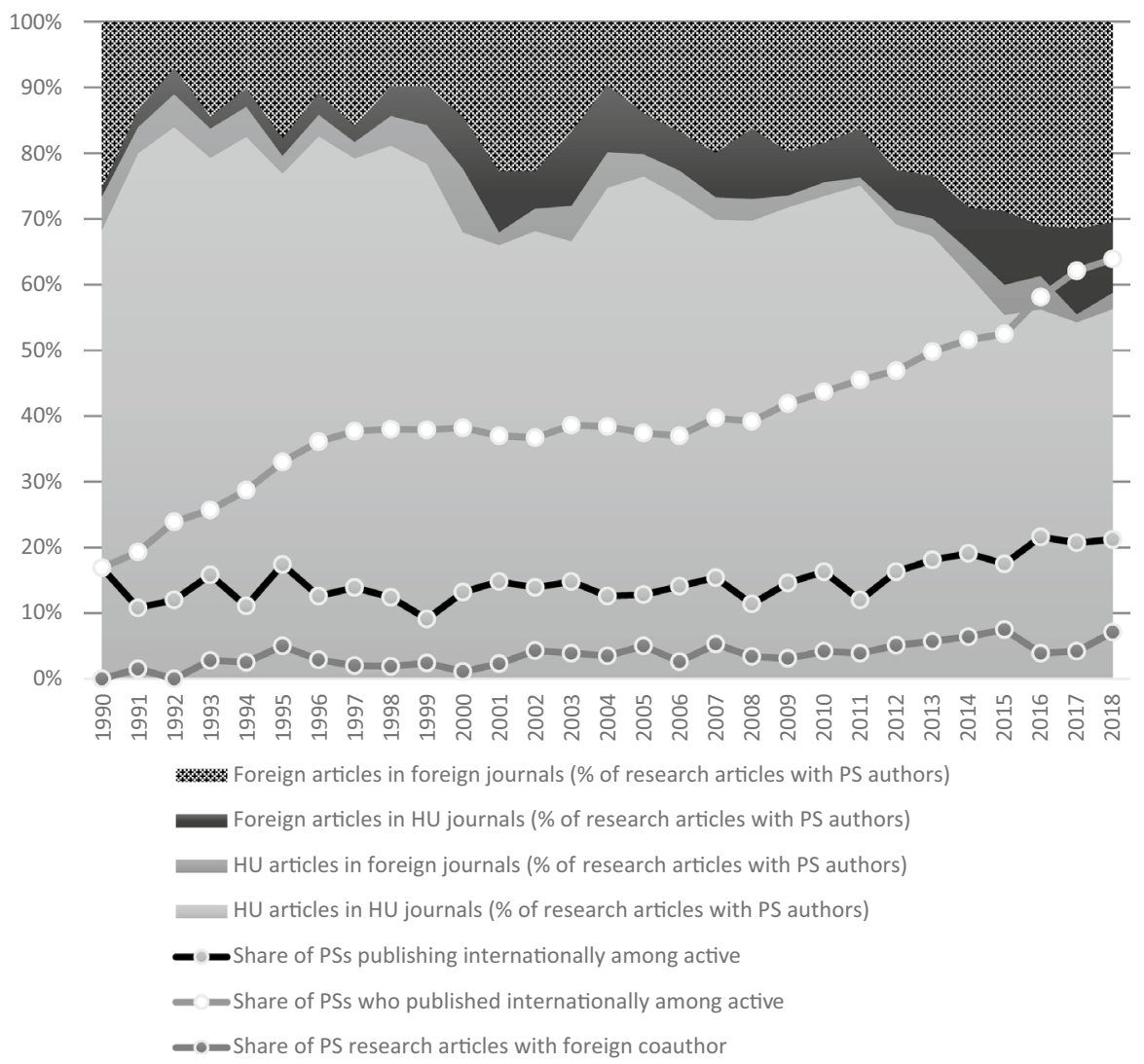

Fig. 5 Internationalisation of the publication activity of Hungarian political scientists

Besides other professions, Fig. 2 and Table 2 draw our attention to an increasingly relevant group: international co-authors. This academic connectedness also contributes to the identity of the profession: In parallel with the increase in quality articles, we can expect a general growth in foreign (especially English) language publication activity, as those articles are more likely to be ranked in international databases. These developments already hint at the increasing international component in publication, but to what degree is Hungarian political science part of European political science, or more broadly, how internationalised is the profession?

\section{Internationalisation}

Figure 5 presents two parallel trends in Hungarian political science. The stacked areas represent the share of publications in foreign languages and foreign journals among all research articles, while the lines represent trends in the personal publication dimension of internationalisation. 
The initial years of the profession show that the early expansion in publication output was mostly concentrated on Hungarian articles. Afterwards, the share of Hungarian language articles in both Hungarian and international journals declined from around eighty-five per cent in the 1990s to less than sixty per cent of overall output in recent years. The share of foreign language articles in foreign journals increased from less than ten per cent to more than thirty per cent, while the share of foreign language articles in domestic journals is steady around ten per cent.

Here we can observe the expected, growing dominance of English, as its ratio among foreign language articles increased from around three-fourths to over ninety per cent. The shrinking, yet continuing relevance of German due to historical and geographical reasons is also worth mentioning, as it decreased from between sixteen and seventeen per cent to around five per cent in the past decade, but had a larger share throughout than all other languages combined in our database.

These general trends show a profession that follows international trends in publication patterns to some degree, but what about the personal side of the equation? How broad and how regular is the internationalisation of the profession? The share of political science articles by Hungarian authors and foreign co-authors increased from virtually none to a still quite low seven per cent. This together with the mass appearance of foreign co-authors is somewhat puzzling (see Fig. 2). The explanation could be that the core political science publication activity of professionals in our sample is less internationalised than their other publications, but it could also be that articles with foreign co-authors are linked to large research projects with group authorship. Since political science research articles with foreign co-authors have a much higher average author count of (2.72 as opposed to 1.16) than those without, with a variance of 13.2 (compared to 0.3 ), the outlier-based explanation seems more likely.

The share of active Hungarian political scientists who published internationally each year varied between ten and fifteen per cent for most of our sample, then increased to just above twenty per cent during the last decade. There seems to be significant variance in the publication activity of different author groups, as the share of active political scientists, who had published internationally at all, steadily increased to above sixty per cent in the meantime. The two major eras of internationalisation seem to be the initial expansion stage and the 2010s, especially its final years. This latter mirrors the expansion in foreign articles as well as the recent increase in regularly internationalised authors. These trends paint a picture of an increasingly internationalised professional community especially compared to earlier results, such as Schneider et al. (2013). However, the still high (almost forty per cent) share of non-internationalised members along with the small (one-fifth) share of those who produce international publications annually suggests a very uneven development of the profession. Internationally indexed articles tend to have more foreign co-authors (see Table 2), so there is a possibility of the emergence of a small, internationally connected, high-performing subgroup within the profession. 
Table 3 The distribution of publication performance among political scientists over time

\begin{tabular}{lllll}
\hline $\begin{array}{l}\text { Average yearly reviewed journal articles by political } \\
\text { scientists for each decade }\end{array}$ & 1990-1999 & 2000-2009 & 2010-2018 \\
\hline Research articles & Mean (median) & $1.91(1.2)$ & $1.84(1.33)$ & $1.84(1.33)$ \\
& SD (skewness) & $1.76(1.64)$ & $1.84(2.22)$ & $1.87(2.03)$ \\
& Non-publishing & $6.0 \%$ & $8.7 \%$ & $9.0 \%$ \\
& Share of top decile & $39.1 \%$ & $27.3 \%$ & $33.0 \%$ \\
Scopus/WoS research articles & Mean (median) & $0.49(0)$ & $0.72(0)$ & $0.51(0)$ \\
& SD (skewness) & $1.93(8.16)$ & $2.06(5.21)$ & $1.45(4.26)$ \\
& Non-publishing & $79.7 \%$ & $74.4 \%$ & $79.0 \%$ \\
& Share of top decile & $85.7 \%$ & $84.2 \%$ & $83.2 \%$ \\
IF/QF research articles & Mean (median) & $0.41(0)$ & $0.6(0)$ & $0.43(0)$ \\
& SD (skewness) & $1.7(8.64)$ & $1.86(5.46)$ & $1.34(4.93)$ \\
& Non-publishing & $81.2 \%$ & $78.7 \%$ & $81.5 \%$ \\
& Share of top decile & $86.3 \%$ & $85.1 \%$ & $86.0 \%$ \\
\hline
\end{tabular}

\section{Uneven development}

Is there a similarly uneven pattern in the distribution of publication performance in general, or in the case of high-quality publications? Table 3 presents the changing distributions of publication activity among Hungarian political scientists on three tiers of publication quality, from reviewed research articles through internationally indexed articles to those appearing in quality factor or impact factor journals.

For the broad research article category, there is a slight decline in the mean yearly performance of political scientists from 1.91 to 1.84 , while the median is consistently lower than that, increasing from 1.2 to 1.33 . This paints a less negative picture of political science than what we expected from Polónyi's (2018) assessment of the decline in publication performance for Hungarian academia as a whole. Standard deviation and skewness metrics suggest a strongly skewed distribution with significant outliers, that is, a large part of our population publishing close to zero research articles per year, with the few high performers increasing the mean. The increasingly uneven distribution was the result of the ratio of non-publishing political scientists increasing slightly, from six to nine per cent, as the share of the top decile of publishing authors in total performance decreased to a level lower than in the 1990s. This divide in the profession between those who actively publish and those who are hardly visible conforms with European standards—good or bad (Kwiek 2015).

The distribution of publications in journals which are internationally indexed, and those which had Impact or Quality Factors show dynamics very similar to all articles. Mean performance increased for the second decade, then returned close to the 1990s level during the last decade. Although the skewness of the distribution of yearly average performance decreased, it remained high throughout the sample. Both the ratio of political scientists not publishing in those categories (between seventy-four and eighty-one per cent) and the share of the top decile in total performance (between eighty-three and eighty-seven per cent) proved remarkably stable. 
These trends suggest that the observed growth in publication output followed by the increasing focus on quality research articles did not really affect the differences between low- and high-performing groups. The profession continues to have a major division between those who are affiliated with central institutions providing resources and incentives for internationally recognised publication activity, and those who publish infrequently. The "two separate worlds" of domestic and international political science research observed for Western countries by Camerlo et al. (2018) seem to hold for the case of Hungary, as well. The Matthew effect of science could be at play here, as those who successfully enter central institutions and international networks are likely to be even more productive over time (Merton 1968). We could view this as the natural result of different institutionalisation paths and the division of labour between research-oriented and teaching- or practice-oriented professional subgroups. One of the major structural problems of Hungarian political science diagnosed in the past decade was the lack of structured networks stemming from the low number of co-author connections (Antal 2011). Our results hint at a profession that was able to overcome these problems for a well-connected, internationalised core group of researchers, but is yet to integrate large parts of its membership into these networks.

\section{Conclusion}

As professions are less and less unified community-due to specialisation and the entry of new subfields - their professional identity remains questionable. This research turned this question around arguing that the diversity of members and changing performance patterns constitute the profession's identity per se. The combined focus on the agency and the performance aspects of Hungarian political science (who are the contributors and what do they perform) provides a vivid picture of the development of the profession and clarified fundamental features of its identity. First, in terms of agents the identity of political science has become more compact. Political scientists - that is those who by institutional position, acclaimed identity and via their performance give face to the group - have achieved a dominant position. At the same time, political science remains colourful, as the share of the contributor group (that is those who are outside the core of the profession both with regard to institutions and identity claims) is around one-third. Overall, it seems that while there is an identifiable and increasingly clear professional community of Hungarian political scientists, the discipline is still open to contributions from outside. The research also shows important changes regarding the performance of political science, especially in the second main dimension: internationalisation. The increased international component of academic output provides international visibility for the profession, and the increasing share of quality publications clearly adds to its status, and possibly its acknowledged institutional position. Political science has become more recognisable for the interested audiences as well.

In looking at these issues in the round, the analysed changes, achievements and bottlenecks all signify the development of the profession's identity. However, publication performance and international recognition are very unevenly shared among 
members of the profession, which could also reflect an uneven access to resources as well as a lack of internal connections within the community. While a national political science community and its institutions continue to develop, its integration into European political science is through the connections and activities of a small group of high-performing professionals in central institutions. This means that the professional community might not be robust, especially when facing challenges to these institutions.

More recent institutional transformations such as the privatisation of universities and the corresponding appearance of new stakeholders (a phenomenon that proved to be consequential in all places (Aarrevaara and Dobson 2013)), or the replacement of institutes and research centres from under the Hungarian Academy of Sciences (Paternotte and Verloo 2020) into a new institutional framework under government authority might threaten the research agenda and the "output" agenda of the profession. Having seen the function of performance in identity formation, we can rightly formulate concerns: how would the identity of our profession transform as a result? To better understand developments in the CEE region (as in all newcomer professional communities), we need a combination of the performance- and personnelcentred and the institutional perspectives, which would allow the study of the relations between professional institutionalisation and the development of underlying professional networks. This would lead to a better understanding of which contexts are more conducive to high-quality research and overcoming the issue of fragmentation through the development of cohesive professional networks, as well as the communities that are more resilient to organisational changes and uncertainty.

Funding Open Access funding provided by Corvinus University of Budapest.

Open Access This article is licensed under a Creative Commons Attribution 4.0 International License, which permits use, sharing, adaptation, distribution and reproduction in any medium or format, as long as you give appropriate credit to the original author(s) and the source, provide a link to the Creative Commons licence, and indicate if changes were made. The images or other third party material in this article are included in the article's Creative Commons licence, unless indicated otherwise in a credit line to the material. If material is not included in the article's Creative Commons licence and your intended use is not permitted by statutory regulation or exceeds the permitted use, you will need to obtain permission directly from the copyright holder. To view a copy of this licence, visit http://creativecommons.org/licen ses/by/4.0/.

\section{References}

Aarrevaara, T., and I.R. Dobson. 2013. Movers and Shakers: Do Academics Control Their Own Work? In The Work Situation of the Academic Profession in Europe: Findings of a Survey in Twelve Countries, ed. U. Teichler and E.A. Höhle, 159-181. Netherlands: Springer. https://doi. org/10.1007/978-94-007-5977-0_8.

Antal, A. 2011. A magyar politikatudomány hiányzó hálózatai [The missing networks of Hungarian political science]. Politikatudományi Szemle 20(1): 132-142.

Berndtson, E. 2021. The Adaptation of New Countries to Existing (Old) Institutional Frameworks. In Opportunities and Challenges for New and Peripheral Political Science Communities, ed. G. Ilonszki and C. Roux. London: Palgrave Macmillan. 
Boban, D., and I. Stanojević. 2021. The Institutionalisation of political science in post-Yugoslav states: Continuities and new beginnings. In Opportunities and Challenges for New and Peripheral Political Science Communities, ed. G. Ilonszki and C. Roux. London: Palgrave Macmillan.

Boncourt, T., I. Engeli, and D. Garzia. 2020P. Political Science in Europe: Achievements, Challenges, Prospects. Lanham: Rowman \& Littlefield Publishers/ECPR Press.

Camerlo, M., D. Doyle, F.G. Diez, and L. Marsteintredet. 2018. The European Political Science Agenda: A Multilevel Analysis from a Country Perspective. European Political Science 17(1): 1-9. https:// doi.org/10.1057/s41304-016-0102-7.

Caza, B.B., and S. Creary. 2016. The Construction of Professional Identity. In Perspectives on Contemporary Professional Work, ed. A. Wilkinson, D. Hislop, and C. Coupland, 259-285. Cheltenham: Edward Elgar Publishing. https://doi.org/10.4337/9781783475582.00022.

Chiva, C. 2007. Political Science in Post-communist Romania. European Political Science 6(1): 24-33. https://doi.org/10.1057/palgrave.eps.2210111.

Drennan, J., M. Clarke, A. Hyde, and Y. Politis. 2013. The Research Function of the Academic Profession in Europe. In The Work Situation of the Academic Profession in Europe: Findings of a Survey in Twelve Countries, ed. U. Teichler and E.A. Höhle, 109-136. Berlin: Springer. https://doi. org/10.1007/978-94-007-5977-0_6.

Eisfeld, R., and L.A. Pal. 2010. Political Science in Central-East Europe and the Impact of Politics: Factors of Diversity Forces of Convergence. European Political Science 9(2): 223-243. https://doi. org/10.1057/eps.2010.11.

Gebethner, S., and R. Markowski. 2002. Political science-Poland. In Three Social Science Disciplines in Central and Eastern Europe: Handbook on Economics, Political Science and Sociology, 19892001, ed. M. Kaase, V. Sparschuh, and A. Wenninger, 306-321. Social Science Information Centre (IZ): Collegium Budapest.

Gel'man, V . 2015. Political Science in Russia: Scholarship without Research? European Political Science 14(1): 28-36. https://doi.org/10.1057/eps.2014.33.

Ghica, L.A. 2020. From Imagined Disciplinary Communities to Building Professional Solidarity. In Political Science in Postcommunist Europe, ed. T. Boncourt, I. Engeli, and D. Garzia. Lanham: Rowman and Littlefield Publishers/ECPR Press.

Henriksen, D. 2016. The Rise in Co-authorship in the Social Sciences (1980-2013). Scientometrics 107(2): 455-476. https://doi.org/10.1007/s11192-016-1849-x.

Holl, A., Makara, G., Micsik, A., \& Kovács, L. 2014. MTMT: The Hungarian Scientific Bibliography. Uses of open data within government for innovation and efficiency, Samos. https://www. w3.org/2013/share-psi/wiki/images/7/79/Samos-MTMT.pdf.

Ilonszki, G., \& Roux, C. (2019). The State of Political Science in Europe. ProSEPS Report by Working Group 1. Report to EU COST Action ProSEPS - Professionalisation and Social Impact of European Political Science. http://proseps.unibo.it/wp-content/uploads/2019/09/Working-Group-1-Repor t-The-State-of-Political-Science.pdf

Jokić, M., A. Mervar, and S. Mateljan. 2019. The Development of Political Science in Central and Eastern Europe: Bibliometric Perspective, 1996-2013. European Political Science 18(3): 491-509. https ://doi.org/10.1057/s41304-018-0191-6.

Kasapović, M. 2008. Political Science in Croatia 1962-2007. European Political Science 7(2): 237-246. https://doi.org/10.1057/eps.2008.3.

Klingemann, H.-D. 2008. Capacities: Political Science in Europe. West European Politics 31(1-2): 370396. https://doi.org/10.1080/01402380701835181.

Krauz-Mozer, B., M. Kułakowska, P. Borowiec, and P. Ścigaj. 2015. Political Science in Europe at the Beginning of the 21st Century. Krakow: Jagiellonian University Press.

Kwiek, M. 2015. Non-Publishers in European Universities. International Higher Education 82: 10-11. https://doi.org/10.6017/ihe.2015.82.8866.

Larson, M.S. 1977. The Rise of Professionalism: A Sociological Analysis. California: University of California Press.

Mény, Y. 2010. Political Science as a Profession. European Political Science 9: S11-S21. https://doi. org/10.1057/eps.2010.36.

Merton, R.K. 1968. The Matthew Effect in Science: The Reward and Communication Systems of Science are Considered. Science 159(3810): 56-63. https://doi.org/10.1126/science.159.3810.56.

Metz, T., and S. Jäckle. 2017. Patterns of Publishing in Political Science Journals: An Overview of Our Profession Using Bibliographic Data and a Co-Authorship Network. PS: Political Science \& Politics 50(1): 157-165. https://doi.org/10.1017/S1049096516002341. 
Paternotte, D., and M. Verloo. 2020. Political Science at Risk in Europe: Frailness and the Study of Power. In Political Science in Europe. Achievements, Challenges, Prospects, ed. T. Boncourt, I. Engeli, and D. Garcia, 287-310. Lanham: Rowman \& Littlefield pubs/ECPR Press.

Polónyi, I. 2018. A hazai felsőoktatás elmúlt 10 évének néhány gazdasági jellemzője [A few economic features of the last decade of Hungarian higher education]. In A magyar felsóoktatás egy évtizede 2008-2017 (Vol. 2), ed. G. Kováts and J. Temesi. Budapest: Budapest Corvinus Egyetem Nemzetközi Felsőoktatási Kutatások Központja.

Pruvot, E.B., T. Estermann, and V. Lisi. 2018. Public Funding Observatory Report 2018. Brussels: European University Association.

Rose, R. 1990. Institutionalizing Professional Political Science in Europe: A Dynamic Model. European Journal of Political Research 18(6): 581-603. https://doi.org/10.1111/j.1475-6765.1990.tb00249.x.

Sasvári, P.L., and A. Nemeslaki. 2019. The Cruelty of Data about Scientific Publication Performance: An Assessment of the Visibility of Hungarian Social Science by Analyzing Hungary's Main Repository. Corvinus Journal of Sociology and Social Policy 10(2): 125-146. https://doi.org/10.14267/ CJSSP.2019.2.7.

Schneider, C.Q., D. Bochsler, and M. Chiru. 2013. Comparative Politics in Central and Eastern Europe: Mapping Publications over the Past 20 Years. European Political Science 12(1): 127-145. https:// doi.org/10.1057/eps.2012.27.

Schneider, G. 2014. Nothing Succeeds like Success: The Past and Future of European Political Science. Political Science Research and Methods 2(2): 153-161. https://doi.org/10.1017/psrm.2014.17.

Szabó, M. 2002. Political Science-Hungary. In Three Social Science Disciplines in Central and Eastern Europe: Handbook on Economics, Political Science and Sociology, 1989-2001, ed. M. Kaase, V. Sparschuh, and A. Wenninger, 258-274. Social Science Information Centre (IZ): Collegium Budapest.

Világi, A., D. Malová, and D. Kostova. 2021. Political Science in Central European Democracies under Pressure. In Opportunities and Challenges for New and Peripheral Political Science Communities, ed. G. Ilonszki and C. Roux. London: Palgrave Macmillan.

Publisher's Note Springer Nature remains neutral with regard to jurisdictional claims in published maps and institutional affiliations.

Gábor Tamás Molnár is a Ph.D. Candidate at the Doctoral School of International Relations and Political Science and an Assistant Lecturer at the Department of Public Policy and Management at Corvinus University of Budapest. His research focuses on the institutionalisation, governance and public policy role of professional communities. His Recent and forthcoming publications include Molnár, G. T. (forthcoming in 2021). The Policy Advisory Roles of Hungarian Political Scientists. In Brans, M. and Timmermans, A. (eds). The Advisory Roles of Political Scientists in Europe. Palgrave Macmillan and Molnár, G. T. (2020). What do business associations do? Corvinus Journal of Sociology and Social Policy, 11(1), https ://doi.org/10.14267/CJSSP.2020.1.3.

Gabriella Ilonszki is a Professor Emerita at the Department of Political Science at Corvinus University of Budapest. Her research interests include comparative political studies with a Central and East European focus. Her Recent publications include Coalition Governance in Central Eastern Europe. (co-editor with Torbjörn Bergman and Wolfgang C. Müller). Oxford University Press, 2019; Opposition Parties in European Legislatures. Conflict or Consensus? (co-editor with Elisabetta De Giorgi) Routledge Studies on Political Parties and Party Systems, London and New York, 2018; Ilonszki, G. and A. Vajda (2019) Women's Substantive Representation in Decline: The Case of Democratic Failure in Hungary. Politics and Gender, 2019, 15: 240-261 https://doi.org/10.1017/S1743923X19000072; and Ilonszki, G. and Gy. Lengyel (2018) Irresponsible elites in opposition and government. The Hungarian case. in: Lars Vogel, Ronald Gebauer, Axel Salheiser eds. The Contested Status of Political Elites. At the Crossroads. Routledge, 2018. 185-202. 